\title{
Peran guru dan kepala sekolah dalam pendidikan karakter siswa di SMA Negeri 3 Yogyakarta
}

\section{The role of teachers and headmaster in character education of student of SMA 3 Yogyakarta}

\author{
Ajmain $^{\text {a, }{ }^{*} \text {, Marzuki }}{ }^{\text {b, } 2}$ \\ a, $b$ Program Studi Pendidikan IPS, Program Pascasarjana, Universitas Negeri Yogyakarta \\ ${ }^{1}$ ajmainbima7@gmail.com, ${ }^{2}$ marzukiwafi@yahoo.co.id \\ *korespondensi penulis
}

\begin{tabular}{ll}
\hline Informasi artikel & ABSTRAK \\
\hline Kata kunci: & Tujuan penelitian ini adalah untuk mengetahui peran guru dan kepala sekolah dalam \\
peran guru, & pendidikan karakter siswa. Subjek penelitian adalah kepala sekolah, guru, dan siswa. \\
peran kepala & Teknik pengumpulan data yang digunakan adalah observasi, wawancara, dan \\
sekolah, & dokumentasi. Analisis data dilakukan dengan teknik analisis deskriptif kualitatif. Hasil \\
pendidikan & penelitian ini menunjukkan bahwa peran guru dalam pendidikan karakter siswa di SMA \\
karakter & Negeri 3 Yogyakarta yaitu; (a) sebagi pendidik yaitu, peran yang berkaitan dengan \\
& tugas memberikan bantuan dan dorongan terhadap aturan-aturan sekolah dan norma \\
& hidup dalam keluarga dan masyarak; (b) sebagai teladan yaitu, guru menjadikan dirinya \\
& sebagai panutan bagi siswa (c) motivator yaitu, dengan adanya kemampuan guru dalam \\
& membangkitkan spirit, etos kerja, dan potensi yang luar biasa dalam diri peserta didik; \\
& (d) sebagai pengajar dan pembimbing yaitu, setiap guru harus memberikan \\
& pengetahuan, keterampilan pada siswa. Selain itu, peran kepala sekolah dalam \\
& pendidikan karakter siswa yaitu sebagai berikut: (a) manajer yaitu, sebagai penentu \\
& kebijakan yang mampu mengakomodir seluruh kebutuhan siswa terkait pendidikan \\
& karakter; (b) pemimpin yaitu, memberikan petunjuk dan pengawasan, kemampuan \\
& mengambil keputusan, dan kemampuan berkomunikasi; (c) mendorong semua guru dan \\
& karyawan untuk menjadi model karakter yang baik bagi semua siswa.
\end{tabular}

\begin{tabular}{ll}
\hline Keywords: & ABSTRACT \\
the role of & The purpose of this study was to determine the role of teachers and principals in \\
teacher, & character education of students. Subjects were principals, teachers, and students. Data \\
the role of & collection techniques used were observation, interviews, and documentation. Data was \\
headmaster, & analyzed using qualitative descriptive analysis techniques. The results of this study \\
character & indicate that the role of teachers in character education of students at state senior high \\
education. & school 3 Yogyakarta, namely; $($ a) as a educator, namely, the role associated with the \\
& task of providing assistance and encouragement of school rules and norms of life in \\
families and communities; $(b)$ as an example, namely, the teachers make itself as a role & model for students, $(c)$ a motivator that is, with the teacher's ability to evoke the spirit, \\
& work ethic and tremendous potential in the self-learners; $(d)$ as teachers and mentors \\
& that is, every teacher must provide the knowledge, skills in students. In addition, the \\
principal's role in character education of students is as follows: $(a)$ the manager is, as \\
a policy maker who is able to accommodate all the students' needs related to character \\
education; (b) leader, namely, provide guidance and oversight, decision-making \\
capacity, and the ability to communicate; $(c)$ Encourage all teachers and employees to \\
become a model of good character for all students.
\end{tabular}

\section{PENDAHULUAN}

Pendidikan merupakan suatu proses pembinaan penguasaan pengetahuan, teknologi, keterampilan, seni, dan moral (karakter) bagi peningkatan daya saing manusia sebagai individu, yang selanjutnya dapat memberikan sumbangan kepada keberdayaan masyarakat lokal, kepada masyarakat bangsanya, dan akhirnya kepada masyarakat global. Karakter adalah nilai-nilai yang melandasi perilaku manusia berdasarkan norma agama, kebudayaan, hukum/konstitusi, 
adat istiadat, dan estetika. Dengan demikian, pendidikan karakter adalah upaya mengembangkan karakter (virtues) yang mencakup kebiasaan dan semangat yang baik, sehingga siswa menjadi pribadi yang bertanggung jawab dan dewasa. Oleh karena itu, untuk membina siswa yang berkarakter atau berakhlak mulia di lingkungan sekolah maka perlu adanya peran guru dan kepala sekolah dalam membina siswa berkarakter. Kepala Sekolah mempunyai peranan dan tanggung jawab dalam menjalankan fungsinya untuk merencanakan pendidikan karakter, mengorganisasikan pendidikan karakter, melaksanakan pendidikan karakter, dan melakukan pengawasan pendidikan karakter.

Pada Pasal 1 Ayat (1) Undang-Undang Republik Indonesia Nomor 20 Tahun 2003 tentang Sistem Pendidikan Nasional menegaskan bahwa pendidikan adalah usaha sadar dan terencana untuk mewujudkan suasana belajar dan proses pembelajaran agar peserta didik secara aktif mengembangkan potensi dirinya untuk memiliki kekuatan spiritual keagamaan, pengendalian diri, kepribadian, kecerdasan, akhlak mulia, serta keterampilan yang diperlukan dirinya, masyarakat, bangsa dan negara.

Menurut ketentuan undang-undang sisdiknas tersebut, fungsi pendidikan nasional tiada lain adalah mengantarkan generasi muda selaku pihak terdidik agar berkembang kemampuannya serta terbentuk watak dan peradaban bangsa yang bermartabat. Jadi, Secara umum, pendidikan karakter dimaksudkan untuk membantu siswa memahami, menyadari, dan mengamalkan nilai-nilai yang baik dalam kehidupan.

Proses pendidikan yang diselenggarakan dan dilaksanakan suatu bangsa dalam upaya menumbuhkan, dan mengembangkan watak atau kepribadian bangsa, memajukan kehidupan bangsa dalam berbagai bidang kehidupannya, serta mencapai tujuan nasional bangsa, itulah yang disebut dengan sistem pendidikan nasional (Hasbullah, 2015; p. 122).

Inilah yang dikatakan oleh Lickona (2014; p. 72) bahwa karakter terbentuk dari pengetahuan moral, perasaan moral, dan perilaku moral. Karakter yang baik terdiri atas mengetahui kebaikan, menginginkan kebaikan, dan melakukan kebaikan-kebaikan pikiran, kebiasaan hati, kebiasaan perbuatan. Ketiganya faktor pembentukan kematangan moral, dan berpikir. Pendidikan tidak hanya mengarah kepada pencapaian psikomotorik, kognitif, namun yang lebih diutamakan adalah perubahan sikap.

Perkembangan zaman yang semakin modern mengindikasikan terjadinya perubahan sikap pada siswa yang dapat menimbulkan suatu kekhawatiran bagi orang tua, dan guru, kepala sekolah selaku lembaga formal bisa mengarahkan hal-hal yang lebih baik pada siswa. Untuk menghindari hal tersebut, maka sebagai lembaga formal atau sekolah perlu adanya peran guru dan kepala sekolah dalam upaya menanamkan pendidikan karakter pada siswa. Oleh karena itu, penanaman nilai-nilai karakter harus dimulai sejak dini baik di lingkungan keluarga, masyarakat, dan yang lebih penting pada lingkungan sekolah.

Perlu disadari bahwa dalam lingkungan sekolah di butuhkan siswa yang memiliki akhlak mulia atau karakter. Oleh sebab itu, kiranya sangat penting peran guru dan kepala sekolah dalam pendidikan karakter siswa karena guru merupakan sosok yang memberi contoh bagi semua siswa dan kepala sekolah merupakan orang yang berperan penting dalam lembaga format, yaitu sebagai management yang mampu mengatur demi lancarnya proses belajar dan mengajar. Hal ini dapat dimaknai bahwa pendidikan itu dapat dipahami sebagai proses melatih siswa untuk mengembangkan pengetahuan melalui sejumlah pengalaman belajar sesuai dengan bidangnya, dan pikirannya, sehingga siswa memiliki karakter unggul menjunjung tinggi nilai etis dalam berinteraksi dengan masyarakat sebagai bagian dari pengabdian dan dalam memenuhi kebutuhan hidup dirinya maupun keluarganya (Sagala, 2013, p.43).

Perlu disadari bahwa dalam suatu lembaga pendidikan formal (sekolah), pendidikan karakter adalah salah satu tujuan utama yang dikembangkan dalam sekolah baik melalui pembelajaran maupun di luar daripada pembelajaran seperti di lingkungan keluarga, dan masyarakat. Hal tersebut di atas 
menunjukkan bahwa pendidikan menuntun segala kekuatan kodrat yang ada pada anak didik itu, agar mereka sebagai manusia dan sebagai anggota masyarakat dapatlah mencapai keselamatan dan kebahagiaan yang setinggi-tingginya (Dewantara, 2013, p.20).

Sistem pendidikan yang sesuai untuk dapat menghasilkan siswa yang cerdas, dan berakhlak mulia adalah yang bersifat humanis dan memosisikan siswa sebagai pribadi dan sekaligus sebagai anggota masyarakat yang perlu dijadikan contoh agar memiliki kebiasaan perpaduan antara keinginan, pengetahuan, dan keterampilan sehingga siswa memiliki nilai-nilai moral yang baik pada dirinya.

Inilah yang dikemukakan oleh Tilaar \& Nugroho (2012, p.283) bahwa pendidikan ditunjukkan untuk mengembangkan kepribadian secara penuh dengan berupaya keras membangun manusia yang sehat pikiran dan badan, mencintai kebenaran dan keadilan, menghormati manusia, menghargai kerja, mempunyai rasa tanggung jawab yang dalam, dan memiliki semangat independen sebagai pembangun negara dan masyarakat yang damai.

Untuk menjadikan siswa agar memiliki sikap, akhlak (karakter), budi pekerti yang baik tidak terlepas dari peran para praktisi dalam hal ini guru dan kepala sekolah sebagai peran utama dalam sebuah lembaga pendidikan formal (sekolah). Oleh karena itu, dalam usaha mewujudkan siswa menjadi insan yang berakhlak mulia serta mampu memberikan kontribusi dalam kehidupan sosialnya. Beberapa penghargaan yang telah diraih oleh SMA Negeri 3 Yogyakarta ini merupakan hasil atau Output dari peran bagaimana usaha kepala sekolah beserta guru dalam menanamkan nilai-nilai yang positif dalam konteks pendidikan karakter.

\section{METODE PENELITIAN}

Pendekatan yang digunakan dalam penelitian ini adalah kualitatif deskriptif dengan menggunakan pendekatan studi kasus. Penelitian studi kasus adalah pendekatan kualitatif yang penelitiannya mengeksplorasi kehidupan nyata, sistem terbatas kontemporer melalui kumpulan data yang detail dan mendalam yang melibatkan beragam informasi atau sumber informasi (Creswell, 2014, p. 135). Data dikumpulkan dengan melakukan wawancara tatap muka secara mendalam. Wawancara ini dipandu oleh pertanyaan riset tetapi tidak terstruktur sehingga memungkinkan penemuan beberapa ide dan tema baru (Creswell, 2014, p.491). Dalam penelitian kualitatif, pengumpulan data dilakukan pada natural setting (kondisi yang alamiah), sumber data primer, dan teknik pengumpulan data lebih banyak pada observasi berperan serta (participant observation), wawancara mendalam (in depth interview) dan dokumentasi (Sugiyono, 2013, p.309).

Teknik-teknik pengumpulan data yang digunakan dalam penelitian ini diuraikan sebagai berikut: (1) Observasi yang dilakukan oleh peneliti antara lain adalah (a) pengamatan langsung terhadap perilaku guru/pembina, perilaku siswa, perilaku kepala sekolah, perilaku karyawan, perilaku tenaga pendidik lainnya, (b) pengamatan sendiri terhadap pelaksanaan ibadah dan alamiah yang dilakukan siswa di lingkungan sekolah, (c) mencatat secara langsung terhadap fenomena yang muncul pada saat pengamatan terhadap semua responden/informan yang terlibat langsung ataupun tidak langsung, (2) wawancara yang digunakan peneliti dengan cara mengajukan pertanyaan-pertanyaan secara lisan dan tertulis. Wawancara tersebut peneliti lakukan dengan kepala sekolah, wakil kepala sekolah, guru/wali kelas, dan beberapa siswa yang dianggap mewakili siswa-siswa yang lain. Seluruh pertanyaan diketahui dan dipahami secara mendalam tetapi tidak terlalu ketat agar tidak terkesan kaku sehingga dapat menyesuaikan dengan situasi dan kondisi di lapangan, dan (3) dokumentasi, yaitu yang digunakan untuk melihat tentang berbagai yang telah atau pernah terjadi yang berkaitan dengan perilaku siswa. Dalam hal ini peneliti melihat dan membaca antara lain catatancatatan khusus tentang pelanggaran siswa terhadap peraturan yang berlaku dan juga tentang peraturannya itu sendiri.

\section{HASIL PENELITIAN DAN PEMBAHASAN}

Nilai-nilai Karakter di SMA Negeri 3 Yogyakarta 
Pendidikan nilai merupakan nurani, sebagai upaya pembinaan terhadap nilai yang ada pada diri manusia dalam hal ini siswa, berkembang menjadi perilaku dan cara lembaga sekolah menanamkan karakter terhadap siswa. Nilai nurani meliputi kejujuran, keberanian, cinta damai, keandalan diri, potensi, disiplin, tahu batas, kemurnian, dan kesesuaian sehingga bisa melakukan komunikasi yang baik antara satu dengan yang lainnya tanpa ada perbedaan.

Nilai adalah segala hal yang berhubungan dengan tingkah laku manusia mengenai baik atau buruknya yang diukur oleh agama, tradisi, etika, moral, dan kebudayaan yang berlaku dalam masyarakat (Zakiyah \& Rusdiana, 2014, p.15). kaitannya dengan nilai-nilai karakter maka peneliti mencoba menjelaskan hasil wawancara peneliti dengan salah satu guru di sekolah ini yaitu dengan Pak Agus, beliau adalah wakil kepala sekolah yang menyatakan bahwa nilai-nilai karakter yang ditanamkan pada siswa seperti yang dijelaskan berikut ini: dengan segala macam versinya sampai dengan tema pengembangan sekolah kita sebagai sekolah kepemimpinan school of the leadership sehingga nilai-nilai karakter yang ditanamkan adalah kepemimpinan, maksudnya bukan dalam artian bukan kepemimpinan formal saja akan tetapi kepemimpinan dalam artian lebih luas termasuk memimpin dirinya sendiri. Kemudian sekolah melatih anak-anak dengan suatu program-program kegiatan kira-kira mendukung merekomendasikan misalnya, kegiatan-kegiatan yang mereka laksanakan sekolah hanya memberikan pendampingan. Jadi, misalnya ulang tahun sekolah, ulang tahun sekolah dilaksanakan oleh siswa akan tetapi sekolah memberikan tim namanya tim pendampingan, kegiatan-kegiatan seperti kunjungan lapangan misalnya kemudian sekolah juga akan memberikan dampingan, dan ini antara lain untuk kemandirian tadi sehingga si anak akan mampu memimpin dirinya sendiri (W11/AS/01/03/16).

Secara garis besar, pembelajaran nilai di sekolah teraktualisasi melalui pembelajaran. Dengan kata lain, nilai diajarkan dan diuraikan berawal dari pembelajaran dan kode etika nilai untuk dipahami oleh siswa melalui pembelajaran. hasil wawancara peneliti dengan salah satu guru yang menyatakan bahwa: Nilai-nilai karakter yang ditanamkan pada siswa bagi saya yang paling utama yang saya ajarkan yaitu karakter kedisiplinan, lalu yang kedua itu kejujuran, karena bagi saya kedua nilai tersebut sangat penting untuk siswa, misalnya disiplin waktu baik waktu belajar, waktu datang ke sekolah dengan tepat waktu, kemudian jujur dalam berbuat baik di lingkungan sekolah terutama kepada kedua orang tua. Dengan memiliki nilai-nilai karakter tersebut tentu peserta didik akan memiliki akhlak mulia sebagaimana yang dilakukan oleh siswa di sekolah ini, misalnya memberi salam ketika bertemu, mencium tangan guru, tutur kata yang baik (W2/ES/28/01/16).

Tujuan utama menanamkan kedisiplinan pada siswa bukan memberikan rasa takut pada siswa, melainkan untuk mendidik para siswa agar sanggup mengatur dan mengendalikan dirinya dalam berperilaku serta bisa memanfaatkan waktu dengan sebaik-baiknya (Naim, 2012, p.148). Nilai-nilai karakter yang ditanamkan oleh Bapak/Ibu guru pada siswanya bisa dikatakan beragam sehingga terintegrasi semua, hal ini sebagaimana yang dikatakan oleh Pak Isdiono salah satu guru yang mengajar mata pelajaran sejarah, yang mengatakan bahwa nilai-nilai karakter itu terintegrasi semua yang kita tanamkan, misalnya kejujuran, keadilan, kedisiplinan, religius, sopan santun, mandiri, kreatif, sehingga dengan kita menanamkan nilai-nilai krakter tersebut siswa memiliki akhlak yang baik. (W4/Isd/28/01/16).

Berkaitan dengan pendapat Bapak/Ibu guru di atas sangat relevan dengan pendapatnya Lickona (2014, p.65) bahwa kejujuran adalah salah satu bentuk nilai yang harus diajarkan di sekolah. Jujur dalam berurusan dengan orang lain, tidak menipu, mencurigai, atau mencuri dari orang lain merupakan sebuah cara mendasar untuk menghormati orang lain.

Nilai-nilai karakter merupakan kewajiban bagi pengajar agar selalu menanamkan dan mengajarkan pada siswa dengan tujuan agar siswa menjadi siswa yang paham terhadap pentingnya nilai-nilai karakter, dan menjadi siswa yang berkarakter mulia. Oleh karena itu, nilai-nilai karakter yang ditanamkan oleh 
Bapak/Ibu guru di sekolah ini dapat kita ketahui melalui wawancara pada waktu peneliti melakukan penelitian di SMA Negeri 3 Yogyakarta yaitu, nilai-nilai karakter yang kami tanamkan pada siswa seperti, religius, terkait dengan ketuhanan itu baik dengan keyakinan karena kalau seseorang agamanya bagus maka kehidupannya juga pasti bagus, dan itu yang saya lakukan, kemudian setiap awal semester saya tidak pernah langsung masuk ke materi akan tetapi mengajari anakanak bahwa yang paling penting sebenarnya bagaimana kita melaksanakan perintahperintah Tuhan. (W3/Hr/28/01/16).

Dari hasil wawancara tersebut sejalan dengan pendapatnya Marzuki (2015, p.69) bahwa dalam keluarga, orang tualah yang menjadi tempat pertama pembentukan karakter anak. Di keluarga inilah anak-anak pertama kali mendapatkan pendidikan akhlak (karakter) di samping juga mendapat sosialisasi berbagai hal yang tumbuh dan berkembang dalam keluarga. Dalam keluarga, anak banyak melakukan proses pendidikan nilai dari orang tuanya, seperti tentang cara bertutur kata, berpikir, dan bertindak. Orang tualah yang menjadi model utama dan pertama dalam hal pendidikan karakter.

Mengingat pendapat di atas, nilai-nilai karakter yang ditanamkan oleh Bapak/Ibu guru di sekolah adalah nilai-nilai karakter kejujuran sebagaimana yang dikatakan oleh Pak Rudi yaitu, nilai-nilai karakter yang terpenting yang saya tanamkan adalah kejujuran, karena seperti halnya ketika melakukan ujian kita tidak hanya mencari nilai atau poin saja akan tetapi tetap kita utamakan kejujuran dalam hal mengerjakan karena memang yang didapat di sekolah itu tidak hanya nilai namun yang lebih penting juga adalah ilmunya, dan kejujurannya. Kejujuran seperti yang dilakukan oleh siswa akan berdampak positif bagi mereka sendiri karena kalau mengawali sesuatu hal yang baik itu pasti akan banyak hal yang baik pula yang kita dapatkan, misalnya orang lain akan senang terhadap orang yang jujur, dan Alhamdulillah semua siswa di sini mereka sangat-sangat jujur (W6/Rd/02/02/16).

Nilai moral seperti menghormati kehidupan dan kemerdekaan, bertanggung jawab terhadap orang lain, kejujuran, keadilan, toleransi, sopan santun, disiplin diri, integritas, belas kasih, kedermawanan, dan keberanian adalah faktor penentu dalam membentuk pribadi sehingga jika disatukan, seluruh faktor ini akan menjadi warisan moral yang diturunkan dari satu generasi ke generasi berikutnya (Lickona, 2014, p.77).

Unsur-unsur nilai tersebut menjadi tanggung jawab untuk menciptakan kedisiplinan dalam lingkungan sekolah sehingga tercipta siswa yang memiliki sikap yang baik, tanggung jawab serta disiplin dalam menjalankan aktivitasnya sehari-hari, hal ini sebagaimana yang dikatakan oleh Ibu Isti yaitu, nilai-nilai karakter utama yang ditanamkan pada siswa adalah tanggung jawab, kemudian selain tanggung jawab yang penting juga adalah kejujuran, sikap kepemimpinan, dan itu tampak sekali yang kita terapkan di sekolah ini, dan ini bisa terbukti dengan event-event yang dikemas oleh siswa sehingga mereka sukses, kemudian Bapak/Ibu guru tinggal mendampinginya saja. Jadi, semua yang jalani itu adalah siswa, seperti itu (W8/Ist/04/02/16).

Sikap hormat, dan bertanggung jawab inilah yang membentuk inti dari moralitas publik secara universal. Kedua nilai ini memiliki kelayakan objektif dan dapat ditunjukkan fungsinya terhadap kebaikan individu maupun kebaikan seluruh masyarakat. Nilai sikap hormat dan tanggung jawab ini sangat penting untuk membangun kesehatan pribadi, menjaga hubungan interpersonal, membangun masyarakat yang demokratis dan berperikemanusiaan serta membentuk dunia yang adil dan damai Lickona (2014, p.61).

Pendidikan karakter secara terintegrasi di dalam pembelajaran dilakukan dengan pengenalan nilai-nilai, memfasilitasi diperolehnya kesadaran akan pentingnya nilai-nilai, dan penginternalisasian nilai-nilai ke dalam tingkah laku peserta didik seharihari melalui proses pembelajaran, baik yang berlangsung di dalam maupun di luar kelas pada semua mata pelajaran. Pada dasarnya kegiatan pembelajaran, selain untuk menjadikan peserta didik menguasai kompetensi (materi) yang ditargetkan, juga dirancang untuk menjadikan peserta didik mengenal, menyadari/peduli, dan 
menginternalisasi nilai- nilai dan menjadikannya perilaku (Triatmanto, 2010, p.192).

Pendidikan Karakter dalam Kegiatan Ekstrakurikuler di SMA Negeri 3 Yogyakarta

Kegiatan ekstrakurikuler merupakan serangkaian program kegiatan belajar siswa di luar jam pelajaran terprogram, yang dimaksudkan untuk meningkatkan cakrawala berpikir siswa dalam menumbuhkan bakat, dan minat serta semangat pengabdian pada masyarakat. Selain itu, kegiatan ekstrakurikuler diharapkan dapat menambah wawasan keilmuan untuk memperoleh pengetahuan baru yang nantinya dapat diadopsi atau dikorelasikan dengan pengetahuan yang diperoleh dari proses belajar mengajar.

Melalui kegiatan ekstrakurikuler ini, bagaimana upaya menumbuhkan pemahaman nilai-nilai karakter atau akhlak yang baik pada siswa, sebagaimana upaya menumbuhkan pemahaman tentang toleransi, berdisiplin, jujur, dan bertanggung jawab. Upaya menumbuhkan pemahaman ini merupakan imbas dari keyakinan dalam mengartikan dan memahami hakikat mengajar dan mendidik. Adanya kegiatan tersebut untuk mendidik siswa menumbuhkan karakternya sebagaimana persepsi Pak Agus mengenai kegiatan ekstrakurikuler yang menyatakan bahwa kegiatan ekstrakurikuler dapat menumbuhkan karakter siswa, seperti etos kerja, misalnya siswa ketika mereka mau melakukan pentas besar mereka harus dengan kerja luar biasa dengan pengorbanan, dengan kombinasi kerja sama. Oleh karenanya, Itu semua termasuk penumbuhan karakter, termasuk sportivitas olahraga juga, kemudian rasa keindahan di seni. Saya pikir dalam kegiatan ekstrakurikuler itu ada semua yaitu bagaimana siswa bekerja dengan tekun, kemudian siswa juga belajar untuk beretika, jujur, dan bertoleransi. Kemudian, yang mengikuti kegiatan ini bukan hanya siswa yang muslim namun yang non-muslim juga. Jadi, toleransi itu penting, kemudian religiusnya artinya, ketika waktunya salat siswa harus salat dulu setelah itu baru melanjutkan (W11/AS/01/03/16).
Kegiatan ekstrakurikuler merupakan bagian dari sekolah secara keseluruhan dalam usaha pencapaian tujuan pendidikan. Kegiatan di luar jam pelajaran dan pada waktu libur sekolah, yang dilakukan sekolah maupun di luar sekolah dengan tujuan untuk memperdalam dan memperluas pengetahuan siswa, mengenal hubungan antar berbagai mata pelajaran. Kegiatan ekstrakurikuler bertujuan untuk menambah serta mengembangkan minat dan bakat yang dimiliki oleh masing-masing siswa secara maksimal, mengembangkan pengetahuannya di bidang seni budaya yang diminatinya dengan melaksanakan kegiatan ekstrakurikuler (Priyanti, Toruan, Sudarman, 2014, p.71).

Peran guru dan kepala sekolah dalam pendidikan karakter siswa adalah sebagai fondasi awal untuk membentuk pribadi siswa sehingga menjadi siswa yang berkompeten baik di bidang akademik maupun nonakademik. Untuk menanamkan karakter bukan hanya melalui kegiatan intra kurikuler namun penanaman pendidikan karakter dilakukan di kegiatan ekstrakurikuler. Hal ini sebagaimana hasil wawancara yaitu, kegiatan ekstrakurikuler yang dapat mendidik siswa berkarakter yaitu pramuka, dan itu wajib untuk kelas X. Dalam pramuka itu kita (siswa) banyak mendapat ilmu dan pengalaman karena dengan melalui kegiatan ekstrakurikuler pramuka kita juga diajarkan oleh kakak senior kita itu bagaimana kita bertanggung jawab dalam perbuatan, bagaimana kita beretika, sopan santun terhadap orang tua, guru, teman, kemudian bagaimana kita hidup bertoleransi dengan teman yang memiliki perbedaan suku, artinya disitu kita diajar untuk berperilaku yang baik dalam kehidupan baik di sekolah, di rumah, dan di masyarakat (W7/Mrn/18/02/16).

Pendidikan Kepramukaan dapat didefinisikan sebagai proses pembinaan dan pengembangan aspek spiritual, emosional, sosial, intelektual, dan fisik pramuka melalui berbagai kegiatan yang edukatif dan menyenangkan agar pramuka menjadi warga negara yang berkarakter dan memiliki kecakapan hidup (life skill), sehingga kegiatan Pramuka mendapatkan ilmu serta berbagai 
materi yang diajarkan dalam Gerakan Pramuka (Wiyani, 2014, p.152).

Kegiatan ekstrakurikuler ini tentu akan dapat memacu semangat siswa untuk berpartisipasi, kemudian tidak terlepas juga dari partisipasi kakak seniornya yang mampu membimbing dan mengayomi selama kegiatan ini berlangsung. Hal ini sebagaimana yang dikatakan oleh siswa yaitu, ekstrakurikuler yang wajib untuk diikuti yaitu Pramuka, kalau yang tidak wajib itu barisberbaris di sini namanya Bayangkara Padmanaba. Jadi, kalau di Pramuka kita tetap diajarkan untuk beretika kemudian dalam baris-berbaris kita juga diajarkan untuk disiplin, baik dalam berpakaian maupun berdisiplin dalam tata tertib, kemudian tata krama biar kita saling menghormati, dan atau etika sopan santun, itu yang paling penting. Intinya kegiatan ekstrakurikuler itu banyak pelajaran yang kita dapatkan terutama mengenai karakter (W10/Ilh/20/02/16). Dengan demikian, dapat dikatakan bahwa kegiatan ekstrakurikuler itu tentu memiliki makna dan fungsi tertentu sebagaimana yang dikemukakan oleh Ratnasari, \& Suharningsih (2013, p.382) yaitu: (a) Pengembangan, yaitu fungsi kegiatan ekstrakurikuler untuk mengembangkan kemampuan dan kreativitas peserta didik sesuai dengan potensi, bakat dan minat peserta didik, (b) Sosial, yaitu fungsi kegiatan ekstrakurikuler untuk mengembangkan kemampuan dan rasa tanggung jawab peserta didik, (c) Rekreatif, yaitu fungsi kegiatan ekstrakurikuler untuk suasana rileks, menggembirakan dan menyenangkan bagi peserta didik yang menunjang proses perkembangan, (d) Persiapan karier, yaitu fungsi kegiatan ekstrakurikuler untuk mengembangkan kesiapan karier peserta didik.

Pendidikan karakter tidak hanya didapatkan dalam intrakurikuler atau proses belajar mengajar yang dilakukan pada saat jam sekolah, namun pendidikan karakter juga bisa dipelajari dengan melalui kegiatan ekstrakurikuler karena dalam kegiatan tersebut terdapat berbagai macam kegiatan yang akan mengasah kemampuan siswa, seperti Paskibraka, pramuka, dan kegiatan ekstrakurikuler lainnya. Oleh sebab itu kegiatan ekstrakurikuler Paskibraka merupakan kegiatan ekstrakurikuler Paskibraka mengajarkan mengenai latihan baris-berbaris namun di dalamnya termuat juga materi kepemimpinan dan organisasi. Paskibraka merupakan kegiatan yang bertujuan untuk memupuk semangat kebangsaan, cinta tanah air, dan bela negara, kepeloporan dan kepemimpinan, berdisiplin dan berbudi pekerti luhur dalam rangka character building generasi muda Indonesia (Ratnasari \& Suharningsih, 2013, p. 380).

Kegiatan ekstrakurikuler merupakan kegiatan tambahan di luar struktur program jam pelajaran biasa guna memperkaya dan memperluas wawasan pengetahuan dan kemampuan siswa, serta dapat menanamkan nilai-nilai karakter atau akhlak yang baik sehingga dengan demikian, pelaksanaan kegiatan ekstrakurikuler akan mampu menumbuhkan dan mengembangkan motivasi internal dalam diri siswa menuju ke arah terbentuknya prestasi belajar yang tinggi serta kemampuan untuk beradaptasi dengan baik. Dengan adanya kegiatan ekstrakurikuler tersebut maka jelas akan menambah khazanah pemikiran, dan ilmu bagi siswa itu sendiri karena melalui pengalaman siswa akan mendapatkan ilmu yaitu dengan kegiatan ekstrakurikuler.

Peran Guru dalam Pendidikan Karakter Siswa di SMA Negeri 3 Yogyakarta

Guru adalah pendidik profesional dengan tugas utama mendidik, mengajar, membimbing, mengarahkan, dan melatih siswa untuk berkompeten baik dalam bidang kognitif, psikomotorik, dan afektif. Guru adalah ujung tombak untuk menentukan tingkat keberhasilan siswa, terutama mengenai afektif dalam hal ini pendidikan karakter. Yusra (2013, p.127) mendefinisikan guru adalah tenaga profesional yang mempunyai tugas dan tanggung jawab mendidik, mengajar, membimbing, melatih, mengarahkan, dan memberi penilaian dan mengevaluasi peserta didik pada pendidikan anak usia dini jalur pendidikan formal, pendidikan dasar, dan pendidikan menengah.

Hal ini senada dengan isi UndangUndang Nomor 14 Tahun 2005 Pasal 1 tentang guru dan dosen menyatakan bahwa Guru sebagai pendidik profesional 
mempunyai tugas utama mendidik, mengajar, membimbing, mengarahkan, melatih, menilai, dan mengevaluasi peserta didik pada pendidikan anak usia dini, pada jalur pendidikan formal, pendidikan dasar, dan pendidikan menengah. Lebih jauh Roqib \& Nurfuadi (2009, p.11) mengemukakan bahwa guru adalah seorang tenaga profesional yang dapat menjadikan murid-muridnya mampu merencanakan, menganalisis, dan menyimpulkan masalah yang dihadapi. Dengan demikian, seorang guru hendaklah bercita-cita tinggi, berpendidikan luas, berkepribadian kuat, dan tegar serta berperikemanusiaan yang mendalam.

Keberhasilan guru dalam pendidikan karakter pada siswa itu tidak terlepas dari bagaimana cara guru melakukan suatu komunikasi yang baik dengan siswanya, dan menemukan metode yang menarik dalam belajar sehingga antara guru dengan siswa tidak ada jarak antara mereka bahkan diantara guru dan siswa peneliti melihat bagaikan hubungan antara anak dengan orang tua. Pendidikan karakter di SMA Negeri 3 Yogyakarta telah tercermin dalam ruang lingkup ke hidup siswa di sekolah. Hal ini membuktikan bahwa siswa-siswa di sekolah tersebut saling menghormati antara satu dengan yang lainnya. Sesuai dengan pernyataan tersebut, sangat relevan dengan hasil wawancara peneliti dengan salah satu guru yaitu, kami selalu menghormati setiap perbedaan yang dimiliki oleh guru, dan siswa. Dengan demikian, anak-anak itu dituntut untuk saling menghargai antara sesama contohnya saya sebagai guru matematika memperlakukan mereka sama meskipun nonmuslim sedikit saya tetap memandang mereka sama. (W2/ES/28/01/16).

Sikap toleransi tersebut dapat dimaknai dengan: (1) tidak memaksakan kehendak kepada orang lain, (2) menghormati orang lain yang berbeda dengannya, (3) mengakui perbedaan dengan mengambil sikap positif (Marzuki, 2015, p.105). Dengan adanya sikap toleransi tersebut maka siswa-siswa diharapkan memperhatikan akan perbuatannya, bagaimana agar semuanya memiliki hati yang bersih untuk selalu berbuat baik kepada teman, guru-guru, dan lebih-lebih pada Tuhan Yang Maha Esa. Pendidikan karakter yang ditumbuh kembangkan oleh pihak sudah tercantum dalam kurikulum 2013 yang mana para guru memberikan pelajaran bukan hanya kemampuan kognitif saja namun yang lebih penting adalah kemampuan afektifnya atau sikap. Hal ini sebagaimana yang dipaparkan oleh responden yaitu, kalau saya pribadi kaitannya dengan peran guru dalam pendidikan karakter siswa kita tidak usah banyak bicara namun berusaha menjadi model yang baik, artinya saya berusaha semaksimal mungkin untuk tidak melanggar, saya semaksimal mungkin untuk bertakwa kepada Tuhan Yang Maha Esa, saya semaksimal mungkin untuk taat terhadap norma yang berlaku, dan berusaha semaksimal mungkin menjadi guru yang beretika, dan kalimat yang singkat adalah saya berusaha menjadi orang yang lebih dewasa daripada anak-anak (siswa) dan kalau saya marah sama anak-anak itu jangan harap pendidikan karakter itu baik, dengan berbuat begitu secara tidak langsung kita telah berperan dalam pendidikan karakter siswa (W3/Hr/28/01/16).

Pernyataan di atas sangat relevan dengan apa yang dikemukakan oleh Sjarkawi (2011, p.33) yang menyatakan bahwa kepribadian yang dimiliki seseorang akan berpengaruh terhadap akhlak, moral, budi pekerti, etika, dan estetika orang tersebut ketika berinteraksi dan berkomunikasi dengan orang lain dalam kehidupan sehari-hari dimanapun ia berada. Selain itu, upaya untuk menanamkan karakter pada siswa dengan mengutamakan kultur bahasa jawa karena memang kultur jawa itu dikenal dengan kultur yang baik, hal ini sebagaimana yang dikatakan oleh salah satu guru yaitu, saya guru bahasa jawa yang ada kaitannya dengan budi pekerti saya selalu menanamkan karakter pada siswa. Pelajaran bahasa jawa itu terselip atau diberikan kepada anak mengenai karakter, sikap sopan santun (patrat), artinya itu sangat penting untuk membekali siswa terutama untuk kalangan SMA. Dengan demikian, tugas saya sebagai guru adalah mengajak dan mendidik siswa. Dengan begitu, kita telah berperan dalam pendidikan karakter siswa itu bukan hanya di sekolah juga namun dalam kehidupan rumah tangga juga. (W7/Ern/04/02/16). 
Dari hasil wawancara tersebut senada dengan hasil penelitian oleh Idrus (2012, p.128) yang berjudul Pendidikan Karakter Pada Keluarga Jawa yang mengemukakan bahwa dalam hal kesopanan bertutur, orang tua dalam masyarakat Jawa akan mengajarkan anak untuk berbicara dengan penuh kesopanan, baik terhadap orang tua, orang yang lebih tua, ataupun dengan orang lain. Perilaku tersebut juga diajarkan pada anak mereka yang masih bayi, saat ada orang lain yang menyapa mereka.

Menyimak pendapat di atas, kaitannya dengan peran guru dalam pendidikan karakter siswa, hal ini sangat relevan dengan pendapat siswa yang menyatakan bahwa peran guru dalam pendidikan karakter siswa guru pasti banyak membantu misalnya untuk kegiatan non-akademik kita dalam setiap menjalankan kegiatan-kegiatan seperti ekstrakurikuler, event ataupun komunitas kita selalu dibimbing sama gurunya. Dengan melalui bimbingan tersebut, guru sudah menanamkan kepedulian terhadap kita. Lalu untuk bagian akademik menggunakan kurikulum 2013. Jadi kebanyakan yang ditekankan itu peran aktif siswa, dengan metode seperti itu otomatis siswa dipacu supaya mereka dapat termotivasi sendiri. (W9/And/18/02/16).

Dari hasil wawancara tersebut dapat dimaknai bahwa segenap pimpinan sekolah, guru, karyawan, petugas parkir atau kebersihan sekalipun, dan masyarakat, secara bersama-sama punya kewajiban untuk membangun kultur sekolah dengan karakter yang baik (Sudrajat, 2011, p.54). Oleh karena itu, peran guru dalam pendidikan karakter siswa tentu setiap guru memiliki cara tersendiri atau metode tersendiri sebagaimana yang dikatakan oleh Ibu Wulan yaitu saya lebih ke mata pelajaran dalam arti proses belajar mengajar. Jadi, ketika dalam kelas saya terapkan lebih baik ketika saya ada di luar kelas, karena ketika dalam kelas kita bisa punya banyak waktu untuk siswa sehingga peran kita dalam pendidikan karakter siswa itu bisa kita terapkan secara langsung, misalkan ketika ada siswa yang duduk di atas meja kita bisa menegurnya langsung bahwa hal itu tidak baik, setelah kita menegurnya anak-anak itu tidak mengulangi hal seperti itu. Melalui pembelajaran kita bisa menanamkan karakter pada siswa ketika mereka berbuat salah kita langsung menasihatinya (W10/Wln/11/02/16).

Pernyataan dari guru tersebut menunjukkan bahwa hasil pembelajarannya ialah terbentuknya kebiasaan berpikir dalam arti siswa memiliki pengetahuan, kemauan dan keterampilan dalam berbuat kebaikan. Melalui pemahaman yang komprehensif ini diharapkan dapat menyiapkan pola-pola manajemen pembelajaran yang dapat menghasilkan anak didik yang memiliki karakter yang kuat dalam arti memiliki ketangguhan dalam keilmuan, keimanan, dan perilaku saleh baik secara pribadi maupun sosial (Akhwan, 2014, p.63).

Untuk mencapai pendidikan karakter yang mulia tentu ada kerja sama antara orang tua murid dengan lembaga formal atau sekolah hal ini tentu merupakan pijakan awal untuk mencapai siswa yang berkarakter. Peran orang tua dan guru dalam pendidikan karakter siswa adalah harapan terbesar untuk siswa, seperti halnya di sekolah sebagaimana hasil wawancara dengan salah satu guru, kita bekerja sama dengan segala pihak baik pihak eksternal maupun internal dalam arti orang tua siswa dan guru, kemudian komite sekolah juga mendukung misalnya pendanaan kemudian alumni sekolah, dan alumni kami selalu bersatu membuat satu organisasi namanya keluarga besar alumni PADMANABA untuk menanamkan karakter pada siswa. (W11/AS/01/03/16).

Dari pendapat di atas sedikit relevan dengan hasil penelitian Koni (2014, p.183) yang mengemukakan bahwa diperlukan kerja sama yang baik antara orang tua dan sekolah agar bisa menghantarkan anak didik dalam upaya mencapai keberhasilan belajar serta mengembangkan potensi sesuai minat dan bakatnya, meraih prestasi dan menjunjung tinggi budi pekerti. Sebagaimana tugas guru untuk memberikan pemahaman tentang budi pekerti di sekolah, hal ini juga menuntut peran serta orang tua secara aktif untuk mengawal anak dalam mengaplikasikan nilai-nilai budi pekerti dalam keseharian di rumah. Terdidiknya siswa yang berakhlak mulia atau berkarakter itu tidak terlepas dari peran guru dan kepala sekolah. Namun, di luar daripada itu yang berperan penting adalah orang tua 
murid sehingga antara sekolah dengan orang tua murid atau masyarakat saling membantu untuk mendidik siswa agar mereka memiliki akhlak yang baik hal ini sebagaimana yang dikatakan oleh guru yaitu, peran keluarga, orang tua siswa, selain itu masyarakat yang ikut berperan aktif juga dalam menanamkan suatu karakter pada siswa, karena waktu di sekolah terbatas waktunya. Jadi, siswa menatap muka sama gurunya itu cuman pada waktu pembelajaran di sekolah. Selain itu, yang bertanggung jawab penuh yaitu keluarga, orang tuanya, dan masyarakat yang berperan aktif atau bertanggung jawab dalam menanamkan pendidikan karakter mereka (siswa) (W2/ES/28/01/16).

Hubungan antara berbagai macam kegiatan ini sangat mendorong untuk membangun peradaban yang berbudi luhur. Kebaikan individu adalah sarana untuk membangun generasi yang berakhlak mulia dalam hal ini sebagaimana yang dikemukakan oleh Marzuki (2015, p.89) bahwa Salah satu upaya untuk mewujudkan pendidikan yang menghasilkan manusia bermartabat (berkarakter mulia), siswa harus dibekali dengan pendidikan khusus yang membawa misi pokok dalam pembinaan karakter mereka. Pendidikan seperti ini dapat memberi arahan kepada para peserta didik setelah menerima berbagai ilmu maupun pengetahuan dalam bidang studi (mata pelajaran) masingmasing, sehingga mereka dapat mengamalkannya di tengah-tengah masyarakat dengan tetap berpatokan pada nilai-nilai kebenaran dan kebaikan yang universal.

Pendidikan karakter yang dilaksanakan di sekolah tidak bisa terlepas dari peran orang tua dan masyarakat yang menjadi lingkungan siswa. Pendidikan karakter tidak akan berhasil jika hanya mengandalkan pendidikan di sekolah. Oleh karena itu, dibutuhkan kerja sama dengan pihak orang tua dan masyarakat dengan berbagai bentuknya demi keberhasilan pendidikan karakter yang dilaksanakan oleh lembaga formal atau sekolah. Hal ini dapat kita lihat sebagaimana yang dikatakan oleh guru yaitu, peran keluarga, orang tua siswa, selain itu masyarakat yang ikut berperan aktif juga menanamkan karakter pada siswa, karena waktu di sekolah terbatas waktunya. Selain itu, yang bertanggung jawab penuh yaitu keluarga, orang tuanya, dan masyarakat yang berperan aktif atau bertanggung jawab dalam menanamkan pendidikan karakter mereka (siswa) (W2/ES/28/01/16).

Mengajari siswa menjadi warga negara yang baik, peduli, dan memiliki semangat publik di sekolah, masyarakat, negara, dan dunia adalah salah satu penawar yang menjanjikan untuk mengobati individualisme yang egois yang melanda budaya kita. Pendidikan kewarganegaraan partisipatif ini membuat siswa belajar untuk peduli dengan memberi pelayanan (Lickona, 2014, p.410). Pendidikan karakter di sekolah dilaksanakan dengan cara integrasi pada kegiatan intrakurikuler maupun ekstrakurikuler, seperti kegiatan kepramukaan, pesantren kilat, membaca doa sebelum dan sesudah pelajaran, memberi salam, dan salat berjamaah sebagaimana yang dikatakan oleh guru yaitu, salat zuhur secara berjamaah yang dilakukan oleh siswa itu adalah pembelajaran religiositas kita bukan paksaan. Jadi, sama dengan disiplin juga. Jadi, kita lebih menciptakan suatu kesadaran seperti kajian juma'at pagi seperti yasinan, dalam kegiatan ini kita tidak melakukan presensi disitu artinya kalau ada anak yang tidak datang itu tidak masalah maka tidak semua siswa bisa mengikuti kegiatan itu, tapi dengan cara itu akan lebih bagus karena kesadaran keagamaan mereka akan lebih baik, jadi istilahnya menumbuhkan budi pekerti karena sekolah sudah memfasilitasi untuk tumbuhnya budi pekerti itu (W11/AS/01/03/16).

Salat zuhur tersebut merupakan salah satu kewajiban yang dilakukan oleh umat muslim sebagaimana yang dilakukan juga oleh siswa yang muslim di SMA Negeri 3 Yogyakarta. Selain itu, adapun kegiatan yang lain yang dapat meningkatkan pengetahuan siswa mengenai moral, agama, akhlak atau karakter dengan melakukan yasinan setiap jum'at pagi, kemudian kegiatan lain juga adalah pembekalan Bimbingan dan Konseling, serta kerohaniaan. Penjelasan tersebut dapat dimaknai bahwa pendidikan karakter tidak hanya mengajarkan mana yang benar dan mana yang salah kepada peserta didik, tetapi juga menanamkan kebiasaan (habituation) tentang yang baik sehingga peserta didik 
paham, mampu merasakan, dan mau melakukannya. Dengan demikian, pendidikan karakter membawa misi yang sama dengan pendidikan akhlak atau pendidikan moral (Marzuki, 2015, p.23).

Menumbuhkan pemahaman nilai-nilai agama sopan santun dalam upaya membiasakan siswa untuk selalu mencium tangan gurunya tiap kali bertemu, dan mengucapkan salam setiap bertemu dengan guru, orang tua, dan teman-temannya merupakan kebiasaan atau awal perbuatan yang baik untuk bersilaturahmi atau berkomunikasi. Dengan demikian dapat dikatakan bahwa nilai utama yang ditanamkan adalah kejujuran misalnya, kejujuran dalam berbuat, kejujuran terhadap sesama siswa, guru, orang tua, dan kepala sekolah seperti itu, namun nilai yang lain yang lebih penting juga yaitu kedisiplinan, misalnya disiplin dalam berpakaian, memakai pakaian yang sudah ditentukan oleh sekolah, kemudian disiplin dalam belajar, disiplin dalam mengerjakan tugas yang diberikan oleh guru, disiplin untuk tepat waktu dalam segala hal, termasuk datang ke sekolah, dan memiliki sikap toleransi terhadap sesama teman tanpa membedakan kultur dan budaya (W1/N/28/01/16).

Pengintegrasian nilai-nilai karakter bangsa ke dalam kegiatan pembelajaran berarti memadukan, memasukkan, dan menerapkan nilai-nilai yang diyakini baik dan benar dalam rangka membentuk, mengembangkan, dan membina tabiat atau kepribadian peserta didik sesuai jati diri bangsa tatkala kegiatan pembelajaran berlangsung (Ghufron, 2010, p.17). Dengan demikian, siswa dapat menerima penanaman kesadaran dan sikap untuk memuliakan Sang Penciptanya yang telah menggerakkan umat manusia, termasuk para siswa, berupa seluruh alam yang dapat diteliti melalui ilmu-ilmu yang bersangkutan, terutama kaitannya dengan pendidikan karakter siswa sebab siswa adalah generasi bangsa yang harus dididik akhlaknya sehingga bisa mewujudkan bangsa yang makmur.

Peran kepala Sekolah dalam Pendidikan Karakter Siswa di SMA Negeri 3 Yogyakarta

Secara sederhana kepala sekolah dapat didefinisikan sebagai seorang guru yang diberi tugas, wewenang, dan tanggung jawab untuk mengepalai dan memimpin suatu organisasi belajar atau tempat dimana proses pembelajaran terjadi. Kepala sekolah pemimpin yang merupakan kemampuan untuk mempengaruhi suatu kelompok ke arah tercapainya tujuan. Kepemimpinan berkaitan dengan kemampuan pemimpin dalam mempengaruhi bawahan dalam sebuah proses interaksi yang bertujuan untuk mencapai suatu organisasi yang baik dalam lingkungan sekolah.

Kepemimpinan kepala sekolah sangat menunjang akan tercapainya pengelolaan sekolah yang efektif dan efisien. Untuk menciptakan sekolah yang efektif dan efisien, kepala sekolah sebagai manajer pendidikan di tingkatan sekolah dan ujung tombak utama dalam mengelola pendidikan diharapkan mampu memegang tugas dan bertanggung jawab memegang peran aktif dalam memajukan sekolah / lembaga pendidikan (Anci, 2014, p.12).

Kepala sekolah merupakan sosok yang mampu ditiru oleh guru siswa, dan stakeholders terutama peran dalam pendidikan karakter siswa. Kepala sekolah memainkan peranan penting dalam menentukan arah, proses, dan pelaksanaan terhadap pendidikan karakter di sekolah. Lickona (2014, p.273) menegaskan bahwa tugas utama sekolah adalah melaksanakan pembelajaran. Bagaimana sekolah dapat membantu siswa agar mengerjakan pekerjaan belajar ini dengan serius, melakukannya dengan segenap kemampuan, dan membangun kualitas karakter yang inheren dengan kapasitas untuk bekerja dengan baik.

Peran kepala sekolah dalam pendidikan karakter siswa di jelaskan oleh pak Agus yaitu yang kepala sekolah tidak bekerja sendirian, kepala sekolah melaksanakan tugas koordinasi, tugas kepemimpinan, tugas management, tugas pengelolaan sehingga nanti pelaksanaan pendidikan karakter ujung tombaknya adalah semua pemangku kepentingan di sekolah. Kepala sekolah, selain itu juga melalui agen-agennya yaitu ada guru, staf-stafnya pembantunya dan semuanya dan itu semuanya dikemas dalam satu program kerja sekolah sehingga guruguru yang bekerja akan bertemu dalam 
program atau mekanisme kerja tersebut. Kepala sekolah sebagai tanggung jawab tunggal sekolah ini yang bertanggung jawab atas semua program yang berlangsung mengenai pendidikan karakter, beberapa program memang menjadi tanggung jawab kepala sekolah namun kepala sekolah membentuk tim kerja disitu dan yang melaksanakannya tim kerja itu nanti kepala sekolah akan melaksanakan fungsi-fungsi pengendalian, tim kontrol setelah evaluasi (W11/AS/01/03/16).

Pelaksanaan pendidikan karakter di sekolah harus melibatkan semua komponen (stakeholders), termasuk komponen-komponen pendidikan itu sendiri, yaitu isi kurikulum, proses pembelajaran dan penilaian, kualitas hubungan, penanganan atau pengelolaan mata pelajaran, pengelolaan sekolah, pelaksanaan aktivitas atau kegiatan kurikuler, pemberdayaan sarana prasarana, pembiayaan, dan etos kerja seluruh warga dan lingkungan sekolah (Emiasih, 2011, p.217). Untuk menciptakan sekolah yang maju dan berkembang dalam berbagai macam aspek itu tidak terlepas dari peran kepala sekolah. Kepala sekolah adalah sebagai ujung tombak dalam keberhasilan sekolah yang dipimpinnya apalagi kurikulum yang digunakan adalah kurikulum 2013 yang menekankan pendidikan karakter tentu dalam hal ini tidak terlepas dari peran kepala sekolah. Oleh karena itu, peran kepala sekolah dalam menanamkan karakter pada siswa yaitu kepala sekolah tidak langsung ya berperan dalam pendidikan karakter siswa namun beliau membuat peraturan, membuat visi misi sekolah lewat, seperti misi sekolah pada poin yang ketiga yaitu menumbuhkan siswa SMA Negeri 3 Yogyakarta sebagai anak Indonesia yang memiliki iman dan takwa, budi pekerti luhur, jiwa kepemimpinan, mandiri, berwawasan kebangsaan, saling menghargai, dan menghormati serta hidup rukun dalam kebhinekaan, baik dalam lingkup lokal, nasional maupun internasional. Dengan begitu, kepala sekolah bisa menanamkan pendidikan karakter selebihnya nanti diajarkan oleh guru. Jadi, walaupun kepala sekolah tidak berperan secara langsung dengan melalui visi misi tersebut kepala sekolah berperan dalam pendidikan karakter siswa-siswanya (W1/Al/16/02/16).

Implementasi pendidikan karakter di sekolah adalah menentukan visi dan misi lembaga pendidikan tersebut. Visi dan misi lembaga pendidikan menjadi prasyarat sebuah program pendidikan karakter di sekolah. Pendidikan karakter di sekolah mencoba memetakan momen-momen khusus yang dapat terjadi dalam lingkup pergaulan di sekolah yang dapat menjadi tempat praktis pendidikan karakter itu dapat dilaksanakan (Buchory \& Swadayani, 2014, p.239). Lebih lanjut peran kepala sekolah dalam pendidikan karakter siswa dapat disimak sebagaimana yang dikemukakan oleh siswa yaitu memberikan instruksi langsung kepada guru bagaimana guru itu mengajarkan pada siswa misalnya bagaimana untuk saling bekerja sama, saling tegur sapa, memberi salam, baik terhadap sesama teman, karyawan, dan guru, berlaku baik pada kedua orang tua, serta berlaku baik kepada seluruh warga sekolah. Jadi, peran kepala sekolah dalam pendidikan karakter siswa kepala sekolah itu meskipun tidak langsung bertatap muka di kelas, namundengan cara seperti tadi bagi saya itu sangat bagus (W3/Skm/17/02/16).

Membentuk karakter siswa sebaiknya kepala sekolah menerapkan strategi keteladanan, kedisiplinan, kepemimpinan instruksional dan mutu, serta pemberdayaan seluruh warga sekolah. Guru sebaiknya menerapkan strategi keteladanan, pembiasaan, dan sentuhan kalbu. Orang tua dan masyarakat sebaiknya menerapkan strategi komunikasi dan kemitraan efektif (Suriansyah \& Aslamiah, 2015, p.245). Mengenai peran kepala sekolah dalam pendidikan karakter siswa sebagaimana yang dikemukakan oleh siswa yaitu dengan melalui upacara, misalnya kita tidak hanya disuruh untuk rajin belajar namun kita juga tetap diberikan bimbingan berupa moral yaitu disiplin, sopan santun, taat kepada kedua orang tua, tanggung jawab, kemudian yang paling besar adalah kita diberikan motivasi untuk melakukan aktivitas-aktivitas keagamaan yang kreatif di sekolah dan itu terbukti bahwa dengan adanya beberapa nilainilai karakter dan motivasi tersebut pasti akan tertanam karakter pada kita. Selain itu, setiap 
kali kita bertemu dengan guru kita selalu mencium tangannya karena itu adalah salah satu nilai sopan santun kita terhadap guru, kira-kira seperti itu (W8/Ssb/18/02/16).

Hal ini senada dengan fungsi kepala sekolah yaitu, (1) kepala sekolah berfungsi dan bertugas sebagai pendidik, manajer, administrator dan supervisor dalam implementasi pendidikan karakter, (2)wakil kepala sekolah adalah membantu kegiatan kepala sekolah dalam: (a) pelaksanaan, (b) pengorganisasian, pengoordinasian, dan pengarahan, (c) pengawasan terhadap ketenangan, (d) penilaian, identifikasi, dan pengumpulan, serta (e) menyusun laporan implementasi pendidikan karakter (Buchory \& Swadayani, 2014, p.242).

Sesuai dengan pernyataan di atas kaitannya dengan peran kepala sekolah dalam pendidikan karakter siswa sangat relevan dengan pendapat salah satu siswa yang, yaitup peran kepala sekolah seperti memberikan atau menyerahkan sepenuhnya kepada guru, selain itu kepala sekolah juga memberikan arahan pada kita waktu upacara, kepala sekolah selalu menasehati kita agar kita selalu tekun untuk beribadah, taat kepada guru, orang tua, bersikap jujur, kemudian berperilaku baik terhadap sesama teman. Selain itu, kita juga selalu diingatkan agar tetap terus bersemangat dalam belajar. Kemudian yang paling besar adalah kita di sekolah ini ada namanya baca yasinan tiap jum'at pagi, itu kegiatan yang paling menyentuh sebab itu menyangkut tentang agama, akhlak, dan karakter kita (W4/Bgs/17/02/16).

Lebih jauh Lickona (2014, p.415) menegaskan untuk menciptakan budaya sekolah agar memiliki moral positif ada lima unsur yang perlu dilakukan yaitu; (a) kepemimpinan moral dan akademis dari kepala sekolah, (b) disiplin dalam lingkungan sekolah yang memberi teladan, mendorong, dan menjunjung tinggi nilai-nilai seluruh lingkungan sekolah, (c) kesadaran komunitas di seluruh lingkungan sekolah, (d) organisasi siswa yang melibatkan para siswa dalam mengurus diri sendiri dan menumbuhkan perasaan "ini adalah sekolah kami, sehingga kami bertanggung jawab untuk menjadikan sekolah terbaik", dan (e) menunjujung arti penting moralitas dengan memberi waktu khusus untuk menangani urusan moral.

Sekolah merupakan lembaga formal bagi siswa untuk mencari ilmu. Di sekolah siswa tidak hanya dituntut untuk memiliki kemampuan kognitif, psikomotorik, namun yang lebih penting adalah afektifnya. Untuk mencapai hal tersebut tentu ada peran di lembaga sekolah terutama dalam hal ini adalah kepala sekolah. Terbentuknya karakter atau akhlak siswa tidak terlepas dari peran kepala sekolah karena kepala sekolah adalah pembimbing, pengayom, dan memberikan yang terbaik buat siswanya. Inilah pentingnya peran kepala sekolah dalam pendidikan karakter siswa karena kepala sekolah adalah pelopor bagi guru, siswa, karyawan khususnya untuk kemajuan dan kebaikan bagi sekolah.

\section{SIMPULAN}

\section{Simpulan}

Hasil penelitian ini menunjukkan bahwa peran guru dalam pendidikan karakter siswa di SMA Negeri 3 Yogyakarta sebagai berikut; (a) sebagai pendidik yaitu, peran yang berkaitan dengan tugas memberikan bantuan dan dorongan terhadap aturan-aturan sekolah dan norma hidup dalam keluarga dan masyarakat; (b) sebagai teladan yaitu, guru menjadikan dirinya sebagai panutan bagi siswa (c) motivator yaitu, dengan adanya kemampuan guru dalam membangkitkan spirit, etos kerja, dan potensi yang luar biasa dalam diri peserta didik; (d) sebagai pengajar dan pembimbing dalam pengalaman belajar yaitu, setiap guru harus memberikan pengetahuan, keterampilan pada siswa; (e) pelajar yaitu, guru selalu mendidik karakter dan keterampilan yang berkaitan dengan tugas kemanusiaan. Sedangkan peran kepala sekolah dalam pendidikan karakter siswa yaitu sebagai (a) manajer yaitu, sebagai penentu kebijakan yang mampu mengakomodir seluruh kebutuhan siswa terkait pendidikan karakter; (b) sebagai pemimpin yaitu, memberikan petunjuk dan pengawasan, kemampuan mengambil keputusan, dan kemampuan berkomunikasi; (c) Mendorong semua guru dan karyawan untuk menjadi model karakter yang baik bagi semua siswa; (d) membentuk dan mendukung 
kerjanya tim budaya sekolah dan karakter dalam memperkuat pelaksanaan dan pembudayaan nilai, norma, dan kebiasaankebiasaan karakter lingkungan sekolah. Selain itu, peran kepala sekolah dalam pendidikan karakter siswa yaitu sebagai berikut: (a) manajer yaitu, sebagai penentu kebijakan yang mampu mengakomodir seluruh kebutuhan siswa terkait pendidikan karakter; (b) sebagai pemimpin yaitu, memberikan petunjuk dan pengawasan, kemampuan mengambil keputusan, dan kemampuan berkomunikasi; (c) Mendorong semua guru dan karyawan untuk menjadi model karakter yang baik bagi semua siswa.

\section{Implikasi}

Berdasarkan simpulan di atas, maka implikasi dalam penelitian ini adalah: (a) penanaman pemahaman tentang pendidikan karakter yang dilakukan oleh guru dan kepala sekolah di SMA Negeri 3 Yogyakarta perlu dipertahankan, (b) penanaman pendidikan karakter yang dilakukan oleh guru dan kepala sekolah dipelihara, dikembangkan, dan ditingkatkan dalam mencari metode yang lebih variatif lagi untuk bisa membentuk siswa yang berkarakter serta kreatif, dan inovatif, (c) guru pendidikan agama Islam dan juga guru mata pelajaran yang lain perlu meninjau dan mengamalkan kembali serta mengevaluasi lagi tentang karakter siswa agar bisa mencapai hasil yang optimal, dan (d) hubungan sekolah dengan masyarakat serta orang tua murid perlu dikembangkan dan dipertahankan agar tercipta sekolah yang mendapatkan nilai positif di masyarakat sehingga bisa menciptakan sekolah yang memiliki siswa yang berkarakter atau memiliki akhlak mulia.

Saran

Pada pelaksanaan penelitian tentang peran guru dan kepala sekolah dalam pendidikan karakter siswa di SMA Negeri 3 Yogyakarta peneliti menemukan beberapa keterbatasan, sehingga peneliti menyarankan kepada peneliti selanjutnya beberapa hal, antara lain:

Pertama, penanaman pemahaman tentang pendidikan karakter yang dilakukan oleh guru dan kepala sekolah di SMA Negeri 3 Yogyakarta perlu dipertahankan.

Kedua, Penanaman pendidikan karakter yang dilakukan oleh guru dan kepala sekolah dipelihara, dikembangkan, dan ditingkatkan dalam mencari metode yang lebih variatif lagi untuk bisa membentuk siswa yang berkarakter serta kreatif, dan inovatif.

Ketiga, guru pendidikan Agama Islam dan juga guru mata pelajaran yang lain perlu meninjau dan mengamalkan kembali serta mengevaluasi lagi tentang karakter siswa agar bisa mencapai hasil yang optimal.

\section{Daftar Pustaka}

Akhwan, M. (2014). Pendidikan karakter: konsep dan implementasinya dalam pembelajaran di Sekolah/Madrasah. Jurnal El-Tarbawi, 61-67.

Anci, R. (2014). Menuju kepala sekolah yang profesional. Jurnal Ekspose Vol. XXIII, 2, 12-22.

Buchory \& Swadayani, T.B. (2014). Implementasi program pendidikan karakter di SMP. Jurnal Pendidikan Karakter Universitas PGRI Yogyakarta Tahun IV, 3, 235-244.

Creswell, J.W. (2014). Penelitian kualitatif \& desain riset memilih diantara lima pendekatan. Yogyakarta: Pustaka Pelajar.

Dewantara, K.H. (2013). Ki Hajar Dewantara: Pemikir, konsepsi, keteladanan, sikap merdeka. Yogyakarta: UST- Press.

Emiasih, D. (2011). Pengaruh pemahaman guru tentang pendidikan karakter terhadap pelaksanaan pendidikan karakter pada mata pelajaran sosiologi di SMA Pius Kota Tegal. Jurnal Komunitas, 216-226.

Ghufron, A. (2010). Integrasi nilai-nilai karakter bangsa pada kegiatan pembelajaran. Jurnal Cakrawala pendidikan, 2, 13-24.

Hasbullah. (2015). Dasar-dasar ilmu pendidikan. Jakarta: PT RajaGrafindo Persada.

Idrus, M. (2012). Pendidikan karakter pada keluarga Jawa. FAI Universitas Islam 
Indonesia Yogyakarta. Jurnal Pendidikn Karakter, 2, 118-130.

Koni, S. (2014). Membangun sumber daya manusia (SDM) bangsa melalui pendidikan karakter. Jurnal IAIN Sultan Amai Gorontalo. 2, 179-186.

Lickona. (2014). Pendidikan karakter. Panduan lengkap mendidik siswa menjadi pintar dan baik. Terjemah oleh Lita S. Bandung: Nusa Media

Marzuki. (2015). Pendidikan karakter islam. Jakarta: Bumi Aksara.

Naim, N. (2012). Character building. Optimalisasi peran pendidikan dalam pengembangan \& pembentukan karakter Bangsa. Jakarta: Ar-Ruzz Media.

Priyanti, W., Toruan, J.L., \& Sudarman, Y. (2014). Pelaksanaan ekstrakurikuler di SMP N 1 Payakumbuh. Jurnal Sendratasik FBS Universitas Negeri Padang, 2, 71-77.

Ratnasari, N.D. \& Suharningsih. (2013). Hubungan kegiatan ekstrakurikuler pasukan pengibar bendera (Paskibra) dengan kepemimpinan peserta didik SMA Kartika IV-3 Surabaya. Jurnal Kajian Moral dan Kewarganegaraan, 1, 379-393.

Republik Indonesia. (2005). Undang-Undang RI Nomor 14, Tahun 2005, Tentang Guru dan Dosen. (2003). Undang-Undang RI Nomor 20, Tahun 2003, Tentang Sistem Pendidikan Nasioanal.

Roqib, M., \& Nurfuadi. (2009). Kepribadian guru. Yogyakarta: Grafindo Litera Media.

Sagala, S. (2013). Etika \& moralitas pendidikan. Peluang dan tantangan. Jakarta: Kencana Prenadamedia Group. Sjarkawi. (2011). Pembentukan kepribadian anak: Peran moral intelektual, emosional, dan sosial sebagai wujud integritas membangun jati diri. Jakarta: PT Bumi Aksara.

Sudrajat, A. (2011). Mengapa pendidikan karakter. Jurnal Pendidikan Karakter,
Universitas Negeri Yogyakarta, 1, 4758.

Sugiyono. (2013). Metode penelitian pendidikan: pendekatan kuantitatif, kualitatif, dan $R \& D$. Bandung: Alfabeta.

Suriansyah, A \& Aslamiah. (2015). Strategi kepemimpinan kepala sekolah, guru, orang tua, dan masyarakat dalam membentuk karakter siswa. Jurnal Cakrawala Pendidikan Universitas Lampung Mangkurat Banjarmasin, 2, 234-247.

Tilaar, H.A.R., \& Nugroho, R. (2012). Kebijakan pendidikan Pengantar untuk memahami kebijakan pendidikan dan kebijakan pendidikan sebagai kebijakan publik. Yogyakarta: Pustaka Pelajar.

Triatmanto. (2010). Tantangan implementasi iendidikan karakter di sekolah. Jurnal Cakrawala Pendidikan, 187-203.

Wiyani, N.A. (2014). Format kegiatan kepramukaan Sebagai ekstrakurikuler wajib di madrasah ibtidaiyah. Jurnal Insania, 19 (1), 148-168.

Dalam kurikulum 2013 Yusra. (2013). Upaya peningkatan efisiensi tenaga guru profesional dalam pencapaian mutu pendidikan. Hunafa: Jurnal Studia Islamika, 1, 127-150.

Zakiyah, Q.Y. \& Rusdiana. (2014). Pendidikan nilai. Kajian teori dan praktik di sekolah. Bandung: CV Pustaka Setia. 